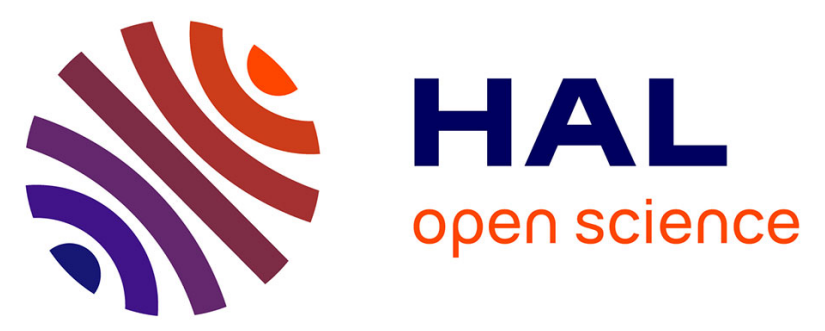

\title{
The effect of soil stoniness on the estimation of water retention properties of soils: A case study from central France
}

Marion Tetegan, Anne C Richer-De-Forges, Bernard Verbeque, Bernard B. Nicoullaud, Caroline Desbourdes, Alain Bouthier, Dominique D. Arrouays, Isabelle I. Cousin

\section{To cite this version:}

Marion Tetegan, Anne C Richer-De-Forges, Bernard Verbeque, Bernard B. Nicoullaud, Caroline Desbourdes, et al.. The effect of soil stoniness on the estimation of water retention properties of soils: A case study from central France. CATENA, 2015, 129, pp.95-102. 10.1016/j.catena.2015.03.008 . hal-02637771

\section{HAL Id: hal-02637771 \\ https://hal.inrae.fr/hal-02637771}

Submitted on 28 May 2020

HAL is a multi-disciplinary open access archive for the deposit and dissemination of scientific research documents, whether they are published or not. The documents may come from teaching and research institutions in France or abroad, or from public or private research centers.
L'archive ouverte pluridisciplinaire HAL, est destinée au dépôt et à la diffusion de documents scientifiques de niveau recherche, publiés ou non, émanant des établissements d'enseignement et de recherche français ou étrangers, des laboratoires publics ou privés.

\section{(ㅇ)(1) $\$$}

Distributed under a Creative Commons Attribution - NonCommercial - NoDerivatives $\mid 4.0$ 


\title{
The effect of soil stoniness on the estimation of water retention properties of soils: A case study from central France
}

\author{
M. Tetegan a, b, c, A. C. Richer de Forges ${ }^{\text {c }}$, B. Verbeque ${ }^{\text {d, B. Nicoullaud }}{ }^{\text {a }}$, C. Desbourdes ${ }^{\mathrm{e}}$,
} A. Bouthier ${ }^{b}$, D. Arrouays ${ }^{c}$ and I. Cousin ${ }^{a^{*}}$

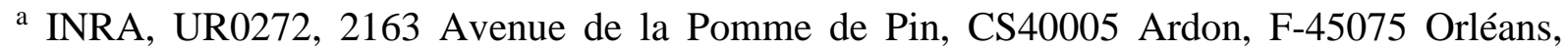
France

${ }^{\mathrm{b}}$ ARVALIS - Institut du Végétal, Domaine du Magneraud, F-17700 Saint Pierre d'Amilly, France

${ }^{c}$ INRA, US1106, 2163 Avenue de la Pomme de Pin, CS40005 Ardon, F-45075 Orléans, France, F-45075 Orléans, France

d Chambre d'Agriculture du Loiret, 13 avenue des Droits de l'Homme, F-45921 Orléans, France

e ARVALIS - Institut du Végétal, 45 voie Romaine, F-41240 Ouzouer le Marché, France

*Corresponding author: Isabelle.Cousin@orleans.inra.fr, (+33) 238414803

\begin{abstract}
Estimation of the water retention capacity of a heterogeneous soil requires knowledge of the hydric properties of each soil phase. Nevertheless, for stony soils, the rock fragments have often been neglected. The objective of this work was then to propose a methodology to improve the calculation of the available water content $(A W C)$ of stony soils at a regional scale. On a 36,200 ha surface area in Beauce located in the Region Centre of France, the $A W C$ was calculated by coupling pedotransfer classes developed for fine earth and rock fragments. When calculating the $A W C$ for the first $120 \mathrm{~cm}$ of the soil and considering the rock fragments to be inert, the $A W C$ was underestimated by $15 \%$ and showed a high spatial variability. When both the volume and the hydric properties of the rock fragments were ignored, the $A W C$ was underestimated by $20 \%$. This work is then the first proposal to estimate soil water properties at a regional scale by using the water storage capacity of the whole stony phase: from gravels to blocks. Results of this study will improve the calculation of water deficit on a regional scale and will aid both in regional water balance modelling and in regional assessment of irrigation needs.
\end{abstract}

Keywords: available water content; water deficit; pedotransfer functions; soil thickness; soil stoniness 
Version définitive du manuscrit publié dans / Final version of the manuscript published in :

Catena, 2015, 129, 95-102 http://dx.doi.org/10.1016/j.catena.2015.03.008

\subsection{Introduction}

To estimate the ability of soils to provide water to plants for their growth, soil scientists and agronomists determine the available water content $(A W C)$ of the soil, which is likely to be exploited by the roots. The $A W C$ is thus an important agronomic parameter for calculating soil water balance and for managing the irrigation of cultivated soils. Therefore, there is a need to explain the soil hydric characteristics to optimize crop growth and to reduce water transfer and losses deeper than the root system. As a consequence, mapping the available water content of soils at a regional scale is a key factor for evaluating land suitability and for developing models to forecast the requirements for irrigation needs and the risks to groundwater quality (Paydar et al., 2009); this mapping is especially important in the context of the climatic change that may alter water reservoir inputs and management in ways that reduce the water supply to irrigated areas (Garcia-Ruiz et al., 2011). As stated by Jensen et al. (2010), new strategies for conserving irrigation water are needed.

Nevertheless, the estimation of the soil available water content remains difficult for heterogeneous soils (Frison et al., 2009), especially stony soils, because it requires a precise knowledge of the water retention capacities of each of the main soil phases: the fine phase composed of soil particles smaller than $2 \mathrm{~mm}$ in diameter and the stony phase composed of rock fragments larger than $2 \mathrm{~mm}$ in diameter (Corti et al., 1998; Tetegan et al, 2011; Wang et al 2013). The calculation of the available water content of the fine phase can be performed through various pedotransfer classes (tables) and pedotransfer functions based on easily accessible soil characteristics such as the bulk density, carbon content and texture of fine earth (Al Majou et al., 2007, 2008a, 2008b; Bastet et al., 1999; Wösten et al., 2001). Pedotransfer classes are tables allowing to obtain the water content of the fine earth thanks to its texture, or by combining its texture and its structure (Al Majou et al., 2005; Bruand et al., 2002). The water retention properties of the stony phase have often been ignored when calculating the available water content of stony soils, although several studies have shown that rock fragments could be a significant water reserve for soil (Gras and Monnier, 1963; Poesen and Lavee, 1994). Tetegan et al. (2011) have also recently proposed new pedotransfer functions and pedotransfer classes to estimate the available water content of rock fragments in soils originating from sedimentary rocks. However, to our present knowledge, no attempt to map and globally assess the available water content of soils at a regional scale has been conducted using these new pedotransfer functions.

The objective of this paper was to use these new pedotransfer functions for estimating the contribution of rock fragments to the available water content of stony soils to i) produce a more accurate map of the available soil water content at the regional scale and, ii) assess if regional estimates of the total available soil water content using the knowledge of this contribution of rock fragments lead to substantial differences from previous approaches. Conducted on several soils of variable stoniness, for each soil type, the available water content was calculated both when considering and when disregarding the volume and the water retention properties of the rock fragments.

\section{Materials and methods}

\subsection{Study area}

The study was conducted on approximately 36,200 ha located $110 \mathrm{~km}$ southwest of Paris in the Patay area within "Petite Beauce". Intensive agriculture in the Petite Beauce often utilizes irrigation and $76 \%$ of the surface area is occupied by cereals crops, mainly maize and 
Version définitive du manuscrit publié dans / Final version of the manuscript published in :

Catena, 2015, 129, 95-102 http://dx.doi.org/10.1016/j.catena.2015.03.008

wheat (Nicoullaud et al., 2004). The climate is temperate continental with an oceanic influence and is characterized by an evapotranspiration of approximately $780 \mathrm{~mm}$ calculated using the Penman-Monteith formula. The average annual temperature was $11^{\circ} \mathrm{C}$ from 1971 to 2000 , and the average annual rainfall was $635 \mathrm{~mm}$ and ranged from 415 to $850 \mathrm{~mm}$ over the 1971 - 2000 period (Richer de Forges and Verbèque, 2003).

\subsection{The Patay soil map and the soil database}

A soil map (scale: 1/50,000) was designed by Richer de Forges and Verbèque (2003) with a mean density of observations equal to 1 auger-hole per 17 hectares. Quantitative data used to create the soil map (granulometry, carbon content, $\mathrm{pH}$, etc...) were measured on approximately 100 soil profiles, using standard analyses, and stored in an associated database. Upper horizons were affected by peri-glacial winds that largely redistributed the fine material (Macaire, 1971, Bourennane et al., 1996), resulting in a rather homogeneous particle-size distribution of the fine earth (i.e., values of silt, clay, sand, etc...). Most of the soils consisted then of a silty-clay layer (approximately 60\% silt and 30\% clay) developed on a lacustrine limestone substrate, which was locally cryoturbated. King et al. (1999) and Bourennane et al. (1998) indicated that the soil units that formed on cryoturbated limestone deposits or on soft limestone deposits had the deepest silty-clay layer (up to $0.8 \mathrm{~m}$ deep), whereas the shallowest soils (approximately $0.3 \mathrm{~m}$ deep) were developed directly on hard calcareous bedrock. This latter bedrock is cracked (Lorain 1973), which could allow a root proliferation of cultures. The study area was classified into 23 main map units (MUs) according to i) the spatial variability of the soil characteristics, ii) the depth and type of limestone where the soil horizons have been developed, and iii) the thickness of the silty-clay layers. Non-stony soils were mainly arenosols, cambisols, fluvisols, luvisols, haplic planosols and vertisols (IUSS Working Group WRB, 2006). Stony soils were mainly rendzic leptosols, haplic calcisols and calcaric cambisols, with various quantities of rock fragments of different sizes, from gravels to blocks (IUSS Working Group WRB, 2006).

The MUs of the soil map consisted of one or several soil units corresponding to a synthetic soil profile defined in terms of soil and agronomic characteristics observed in the field (Legros, 2006). The information on the soil units was stored in the "DoneSol" soil database (Gaultier et al., 1993; Grolleau et al., 2004). From this database, we used the following soil characteristics to estimate the available water content of both the stony and non-stony soils:

- the volume proportion and the texture of the fine phase,

- the volume proportion, the lithological class (limestone, quartz, or flint, on the studied area) and the bulk density of the whole stony phase (gravels, pebbles, stones and blocks),

- the thickness of the horizons

- the nature of the underlying parent material

- the surface proportion of each soil unit in each of the 23 MUs of the map of Patay.

To be comparable with the pedotransfer functions developed by Tetegan et al. (2011) for the estimation of the contribution of rock fragments to the available water content, the bulk density of the rock fragments located within the soil profile was used, rather than the bulk density of the bedrock, the latter that could be slightly different. 
Version définitive du manuscrit publié dans / Final version of the manuscript published in :

Catena, 2015, 129, 95-102 http://dx.doi.org/10.1016/j.catena.2015.03.008

\subsection{Calculation of the available water content at different scales}

\subsubsection{Choice of a definition and units for the available water content}

We define the available water content as the quantity of water that can be used by plants for their growth, and we assume that it is equal to the difference between the water content at field capacity, and the water content at permanent wilting point, with the units $\mathrm{cm}^{3} . \mathrm{cm}^{-3}$, as calculated in equation (1). Nevertheless, for practical reasons, it is also expressed as a depth (expressed in $\mathrm{mm}$ ): it represents the available water within a soil horizon (see equation (2)) or within a soil profile (see equation (3)) and can be directly used in a water balance model.

\subsubsection{Method used to calculate the available water content}

The available water content for both the fine phase and the stony phase $\left(A W C_{i}\right)$ was calculated using equation (1):

$A W C_{i}=\theta_{f c, i}-\theta_{w p, i}$

where $A W C_{i}$ represents the available water content of the phase $i$ in $\mathrm{cm} \mathrm{cm}^{-3}, \theta_{f c, i}$ represents the volumetric soil water content at field capacity for phase $i$ in $\mathrm{cm}^{-\mathrm{cm}^{-3}}$, and $\theta_{w p, i}$ is the volumetric soil water content at the permanent wilting point for phase $i$ in $\mathrm{cm}^{-\mathrm{cm}^{-3}}$. For both the fine phase and the stony phase, the volumetric soil water content at field capacity was set equal to the soil water content at a matric potential of $-100 \mathrm{hPa}$, as suggested by Bruand et al. (2004) and Al Majou et al. (2008a, 2008b) for the fine earth, and by Tetegan et al. (2011) for the stony phase. For both the fine and the stony phase, the volumetric soil water content at permanent wilting point was set equal to the soil water content at a matric potential of -15850 $\mathrm{hPa}$, as typically required. For the fine phase, the volume soil water contents at $-100 \mathrm{hPa}$ and $15850 \mathrm{hPa}$ were calculated from the pedotransfer classes of Bruand et al. (2004). These authors used the soil texture (Baize et al., 2009) from the French texture class triangle of Jamagne (1967) and separated topsoil and subsoil horizons in the soil profile. For our study, the dominant texture of the fine phase for each horizon of each soil unit was collected from the soil database and the position of each horizon in the soil profile was simplified by distinguishing only between topsoil and subsoil horizons. Table 1 presents the $A W C_{i}$ for the fine phase. For the stony phase, the volumetric soil water contents at $-100 \mathrm{hPa}$ and $-15850 \mathrm{hPa}$ were calculated using the pedotransfer classes proposed by Tetegan et al. (2011), who used informations only on the lithological class of the rock fragments and the bulk density of each rock fragment. In our study, the dominant lithological class of the rock fragments was collected from the soil database for each soil horizon. The bulk density of the rock fragments of each lithological class was taken from Tetegan et al. (2011). The $A W C_{i}$ for the stony phase is presented in Table 2.

From the $A W C_{i}$ of both the fine and the stony phases given by Eq. (1), the available water capacity of a horizon $n\left(A W C_{h}^{n}\right)$ was calculated in millimetres by using the equation Eq. (2) proposed by Cousin et al. (2003):

$$
A W C_{h}^{n}=\left(\sum_{i=1}^{i=2} A W C_{i} \times P_{i}^{n}\right) \times T_{h}^{n}
$$

where $P_{i}^{n}$ - collected from the soil database - represents the volume proportion of phase $i$ (fine phase or stony phase) in horizon $n$ and $T_{h}^{n}$ represents the thickness in millimetres of the horizon $n$. 
Version définitive du manuscrit publié dans / Final version of the manuscript published in :

Catena, 2015, 129, 95-102 http://dx.doi.org/10.1016/j.catena.2015.03.008

\section{Table 1}

The pedotransfer classes used in Eq. (1) for the calculation of the available water content $\left(A W C_{i}\right)$ of the fine phase as a function of both the position of the horizon in the soil profile and the texture of the fine earth texture.

From Bruand et al. (2004).

\begin{tabular}{lll}
\hline $\begin{array}{l}\text { Horizon position in } \\
\text { the soil profile }\end{array}$ & $\begin{array}{l}\text { Texture of fine } \\
\text { earth }\end{array}$ & $\begin{array}{l}A W C_{i} \text { of the fine phase } \\
\left(\mathrm{cm} \cdot \mathrm{cm}^{-3}\right)\end{array}$ \\
\hline Topsoil & Clay loam & 0.136 \\
& Sandy clay & 0.173 \\
Silt loam & 0.173 \\
Silt & 0.167 \\
Loam & 0.143 \\
Silty clay loam & 0.213 \\
Clay loam & 0.183 \\
Sandy loam & 0.162 \\
Sandy clay & 0.128 \\
Loamy sand & 0.131 \\
Sand & 0.060 \\
Silty clay & 0.113 \\
Sandy clay & 0.095 \\
& Clay & 0.093 \\
Silt loam & 0.149 \\
Silt & 0.148 \\
Loam & 0.127 \\
Silty clay loam & 0.207 \\
Clay loam & 0.196 \\
Sandy clay & 0.103 \\
Loamy sand & 0.116 \\
Sand & 0.073 \\
\hline
\end{tabular}

\section{Table 2}

Available water content $\left(A W C_{i}\right)$ of the stony phase calculated from the pedotransfer classes of Tetegan et al. (2011).

\begin{tabular}{lll}
\hline $\begin{array}{l}\text { Lithological classes of } \\
\text { rock fragments }\end{array}$ & $\begin{array}{l}\text { Bulk density of rock } \\
\text { fragments }\left(\mathrm{g} \cdot \mathrm{cm}^{-3}\right)\end{array}$ & $\begin{array}{l}A W C_{i} \text { of the stony phase } \\
\left(\mathrm{cm} \cdot \mathrm{cm}^{-3}\right)\end{array}$ \\
\hline Quartz & 2.65 & 0.00 \\
Flint & 2.22 & 0.01 \\
Limestone & 2.18 & 0.03 \\
\hline
\end{tabular}

The available water content of a soil unit $m\left(A W C_{S U}^{m}\right)$ was calculated for its soil profile as the sum of the $A W C_{h}^{n}$ of each horizon (Eq. (3)). From the available water content of each soil unit $\left(A W C_{S U}^{m}\right)$, the available water content of each map unit $\left(A W C_{M U}^{t}\right)$ was calculated according to the equation Eq. (4).

$$
\begin{aligned}
A W C_{S U}^{m} & =\sum_{N=1}^{N} A W C_{h}^{n} \\
A W C_{M U}^{t} & =\sum_{N=1}^{N}\left(A W C_{S U}^{m} \times S_{S U}^{m}\right)
\end{aligned}
$$


Version définitive du manuscrit publié dans / Final version of the manuscript published in :

Catena, 2015, 129, 95-102 http://dx.doi.org/10.1016/j.catena.2015.03.008

In the equation Eq. (3) $N$ represents the number of horizons of the soil unit $m$. In the equation Eq. (4) $N$ is the number of soil units composing the map unit $t$ and $S_{S U}^{m}$ is the surface proportion of the soil unit $m$ in the map unit $t$.

\subsubsection{Choice of a value of soil depth to calculate the AWC}

A fundamental parameter in the estimation of the available water content is the soil depth. In our study, we calculated two values of the $A W C$ to accommodate two definitions of the soil depth:

- For a soil scientist, the soil depth is the thickness of all the soil layers from the surface to the bedrock. The depth of the bedrock, designated here as the "real soil depth" was known from the soil database. The available water content map calculated using the real soil depth $\left(A W C_{\text {soil }}\right)$ can be used to generate a generic map that is useful for many environmental applications.

- For an agronomist, the soil depth corresponds to the rooting depth, which varies considerably with the plant type. In our study, we will focus our calculations on the maize crop because i) it is known for its high water requirement (to reach a maximum production, maize needs from 500 to $800 \mathrm{~mm}$ of water, depending on the climate) (Doorenbos et al., 1978) and ii) it is cultivated over much of the Patay area and typically requires irrigation. The average rooting depth of maize is equal to $120 \mathrm{~cm}$ (B.S.I. Standards., 1988). Therefore, knowing that: i) at the study area, the shallow stony soils are draining soils lying on a cracked calcareous bedrock (Lorain 1973) enabling a storage of the drained water and giving enough spaces between cracks for root proliferation, ii) calcareous bedrock can provide nutrients to plants (Abou-el-Seoud and Abdel-Megeed, 2012; Korboulewsky et al., 2010a; Korboulewsky et al., 2010b), iii) maize roots have a remarkable plasticity by increasing their root length, allowing to capture nutrient resources ( $\mathrm{Li}$ et al., 2012 ), a soil depth of $120 \mathrm{~cm}$ was used to calculate the AWC in this second case $\left(A W C_{\text {maize }}\right)$, regardless of the soil unit and the "real soil depth".

Depending on their locations, soil units exhibited different real soil depths, from a few centimeters to more than one meter (Fig. 1). For the $A W C_{\text {soil }}$ and $A W C_{\text {maize }}$ calculations, soils thicker than $120 \mathrm{~cm}$ were truncated to $120 \mathrm{~cm}$. This truncation ranged from 2 to $31 \mathrm{~cm}$.

For the $A W C_{\text {maize }}$ calculations, soils less than $120 \mathrm{~cm}$ thick were extended to $120 \mathrm{~cm}$. This extension for soils shallower than $120 \mathrm{~cm}$ was mainly necessary for soils that were developed on limestone (cracked calcareous bedrock). This extension ranged from 1 to 109 $\mathrm{cm}$ with a median value of $38 \mathrm{~cm}$. From the depth observed in the field to the depth of 120 $\mathrm{cm}$, we accounted for the rocky parent material and hypothesized that its hydric properties were close to those of the rock fragments in the soils of Patay. This hypothesis was supported by experimental measurements of the water content in soil rock fragments at different depths in the soil profile and at different degrees of alteration (Tetegan et al., 2011).

\subsection{Evaluation of the role of rock fragments in the calculation of the available water content}

The available water contents estimated for two soil depths ( $A W C_{\text {soil }}$ and $\left.A W C_{\text {maize }}\right)$ were calculated according to three scenarios.

- Scenario 1- Under this scenario, the stony soils were considered to contain active rock fragments; we accounted for both the volume proportion of the rock fragments and 
Version définitive du manuscrit publié dans / Final version of the manuscript published in :

Catena, 2015, 129, 95-102 http://dx.doi.org/10.1016/j.catena.2015.03.008

their hydric properties, which were estimated with the pedotransfer classes proposed by Tetegan et al. (2011). This scenario is considered the reference scenario, where soil contains porous rock fragments that may store water.

- Scenario 2- All soils were considered to be $100 \%$ fine earth; the volume of the rock fragments in each soil horizon was replaced by an equivalent volume of fine earth. This scenario is similar to actual scenarios when the available water content is calculated over large scales, for example to create regional maps. In this situation, both the quantity and properties of rock fragments are neglected, and the proportion of rock fragments is replaced by an equivalent quantity of fine earth.

- Scenario 3- The stony soils contained inert rock fragments; we accounted for the volume of the rock fragments but assumed that they could not to store water. This scenario is an intermediate scenario between scenarios 1 and 2; the proportion of rock fragments is high enough that it is usually not neglected in available water content calculations. Nevertheless, their hydric properties, especially their contribution to the available water content, are unknown. In this situation, the proportion of rock fragments is not neglected, but the rock fragments are replaced by nothing (not by the fine earth).

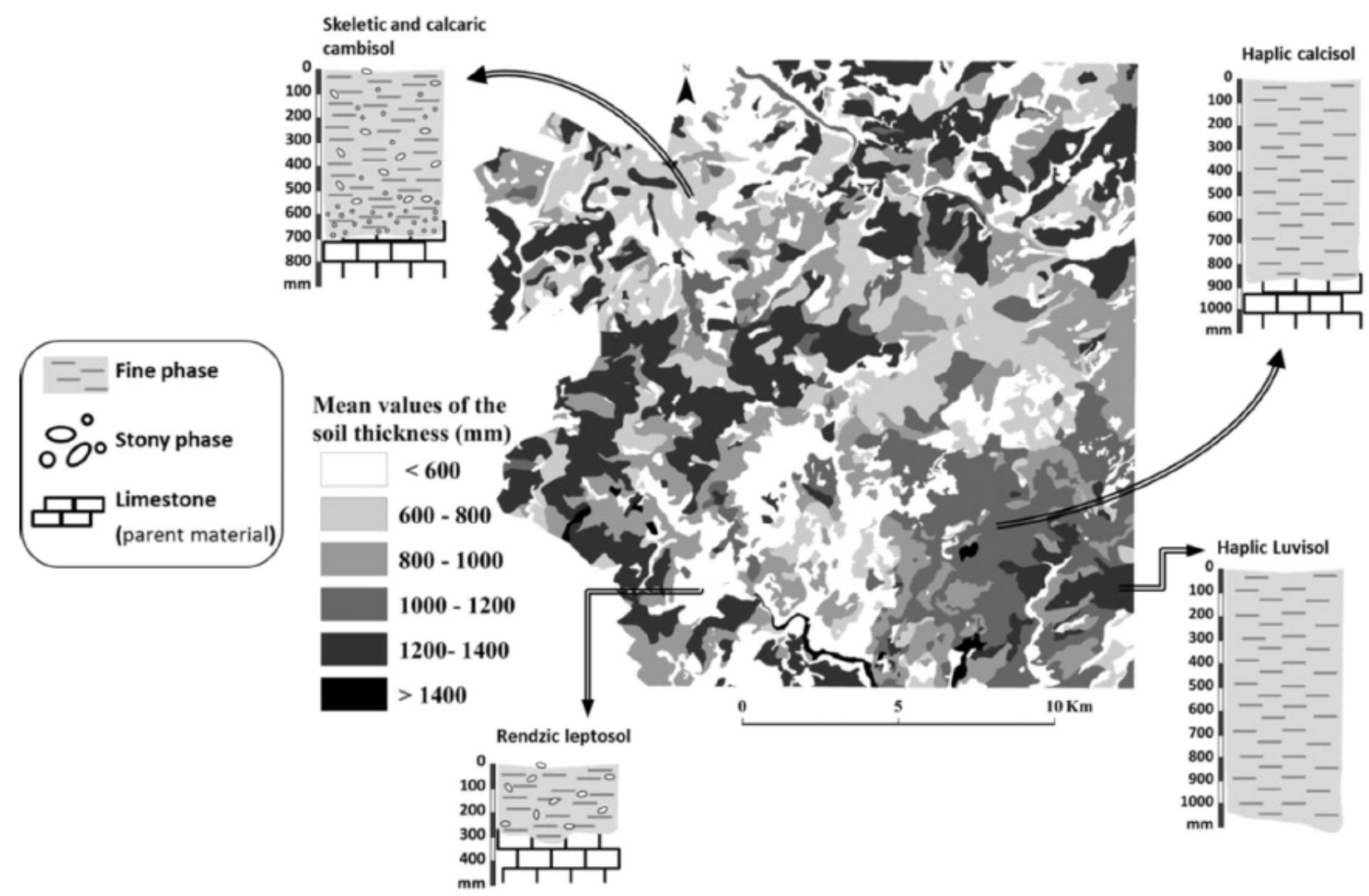

Fig. 1. Map of the soil thickness in the area of Patay. Four synthetic characteristic soil profiles are represented. From Richer de Forges and Verbèque (2003).

Scenarios 2 and 3 were each compared with the reference scenario: for each map unit, we have computed the difference between the reference scenario and another scenario with the following equation:

$$
\triangle A W C=A W C_{j}-A W C_{j r e f}
$$

where $A W C_{j}$ represents the available water content calculated using scenario 2 or scenario 3 and $A W C_{j r e f}$ represents the available water content calculated using scenario 1 . Negative 
Version définitive du manuscrit publié dans / Final version of the manuscript published in :

Catena, 2015, 129, 95-102 http://dx.doi.org/10.1016/j.catena.2015.03.008

values represent under-estimations of the real available water content, whereas positive values represent over-estimations.

To evaluate the global differences between these scenarios at the regional scale, we have also computed the Mean Error $(M E)$, the Mean Absolute Error $(M A E)$ and the Root Mean Square Error (RMSE), using the following equations:

$$
\begin{aligned}
& M E_{A W C}=\frac{1}{N} \sum_{j=1}^{N}\left(A W C_{j}-A W C_{j r e f}\right) \\
& M A E_{A W C}=\frac{1}{N} \sum_{j=1}^{N}\left(\left|A W C_{j}-A W C_{j r e f}\right|\right) \\
& R M S E_{A W C}=\sqrt{\left(\frac{1}{N} \sum_{j=1}^{N}\left(A W C_{j}-A W C_{j r e f}\right)^{2}\right)}
\end{aligned}
$$

where $A W C_{j}$ represents the available water content calculated using scenario 2 or scenario 3 and $A W C_{j r e f}$ represents the available water content calculated using scenario 1.

Exclusively related to the difference between scenarii on the AWC-calculation and not including the errors linked to parameters provided by "DoneSol" soil database, these ME, MAE and RMSE give a theoretical estimate of the quantitative relevance of the contribution of the hydric properties of the stony phase in those of stony soils.

The maps showing the available water content maps were designed with the ArcGis $9^{\circledR}$ software.

\section{Results and discussion}

\subsection{Soil stoniness and soil thickness}

The real soil thickness in the study area varied from $11 \mathrm{~cm}$ to $151 \mathrm{~cm}$ (Fig. 1). The shallowest soils (thickness less than $50 \mathrm{~cm}$, typically Rendzic leptosol) occupied $17 \%$ of the surface of the map. The largest area of the soil map (81\%) was represented by soils with a thickness between 50 and $150 \mathrm{~cm}$. The deepest soils (thickness greater than $150 \mathrm{~cm}$, typically Haplic luvisol) represented only $2 \%$ of the surface of the map and were mainly situated in a band oriented from southwest to northeast (Fig. 1).

The soil stoniness was highly variable in space (Fig. 2a and $2 b$ ). The rock fragments were mainly limestone (78 \%), quartz (13\%) and flint (9\%) (Fig. 2a). The southeast part of the map was occupied by soils containing the smallest percentage of rock fragments (less than $10 \%)$, and was surrounded by rockier soils. Sixty-seven percent of the surface was covered by soils with a mean stoniness less than or equal to $10 \%$, and $31 \%$ was covered by soils with mean stoniness values between $10 \%$ and $30 \%$ (Fig. 2b). Only $2 \%$ of the soil surface of the Patay area demonstrated stoniness above $30 \%$.

The soil stoniness and the thickness were weakly correlated $(\mathrm{R}=0.34)$ (Fig. 3). The thickest soils (thicker than $100 \mathrm{~cm}$ ) were not systematically located in areas with the lowest proportion of rock fragments. However, as expected, the shallowest soils (thickness less than or equal to $30 \mathrm{~cm}$ ) were located in areas with high rock fragments proportions, i.e., between $10 \%$ and $20 \%$ of the soil volume (Figs. 1 and 2). The southwest to northeast band of the map was an area where the soil stoniness and thickness were approximately $20-30 \%$ and 100 $140 \mathrm{~cm}$ respectively.

After substituting the maize rooting depth for the real soil depth, we recalculated the stoniness values for all the MUs (Fig. 2c). In this case, $98 \%$ of the surface area of the Patay map was represented by soils containing rock fragments. Over $50 \%$ of the surface contained 
Version définitive du manuscrit publié dans / Final version of the manuscript published in :

Catena, 2015, 129, 95-102 http://dx.doi.org/10.1016/j.catena.2015.03.008

soils with mean values of stoniness greater than or equal to $35 \%$. The southeast part of the map remained the area containing soils with the fewest rock fragments (composing less than $20 \%$ of the soil volume).

\subsection{Estimation of the soil available water content for the 3 scenarios}

3.2.1. Overview of the available water content calculated for the two depths and the 3 scenarios

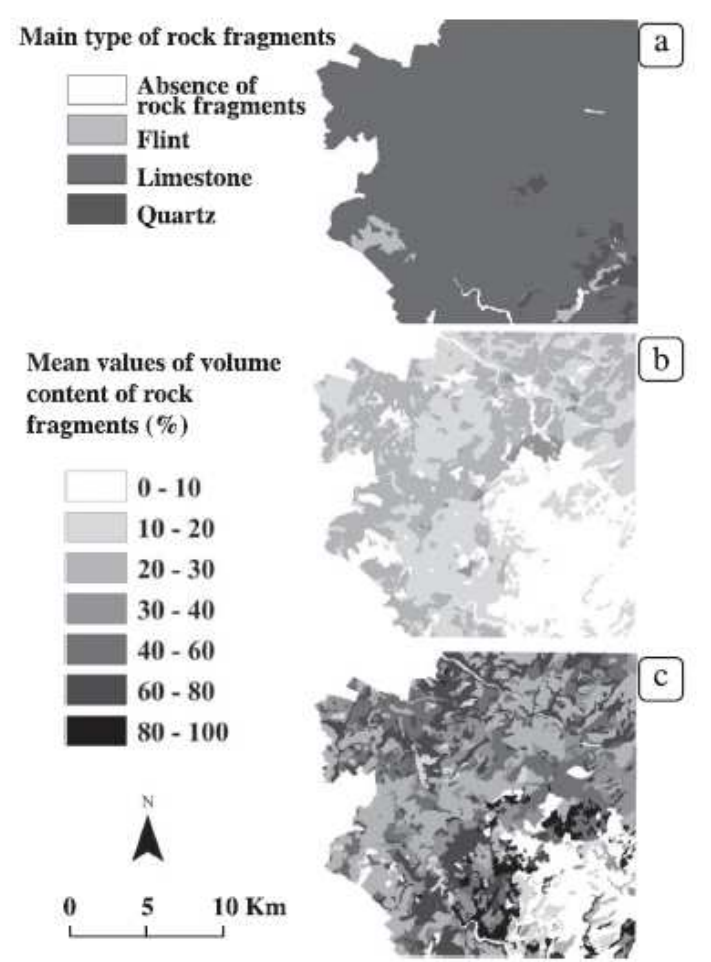

Fig. 2. Rock fragment cantent and types in the area of Patay. a) Primary of rock fragment type; b) rock fragment content observed in the field (information stored in the soil
database; c) rock fragment content recalculated for a soil thickness of $120 \mathrm{~cm}$.

The available water content of the soils in the area of Patay was calculated for each map unit using the two soil depths $\left(A W C_{\text {soil }}\right.$ and $\left.A W C_{\text {maize }}\right)$ and the three scenarios defining the degree to which soil stoniness was considered in the calculations. For the real soil depth neither the range of the $A W C_{\text {soil }}$ values nor the mean or median $A W C_{\text {soil }}$ values varied significantly with the scenario (Table 3 ). As expected, however, the lowest values were recorded for scenario 3, which ignored the water retention properties of the stony phase. The lowest median value (scenario 3) was equal to $105 \mathrm{~mm}$ of water, which corresponded to $1.12 \mathrm{~mm}$ of water by $\mathrm{cm}$ of soil (Table 3). This value is close to $1 \mathrm{~mm} / \mathrm{cm}$, the $A W C$ value usually used for loamy soils developed on loess (Jamagne et al., 1977). The highest median $A W C_{\text {soil }}$ value was recorded for scenario 2: it was equal to $109 \mathrm{~mm}$ of water which corresponded to $1.20 \mathrm{~mm}$ of water by $\mathrm{cm}$ of soil.

When the maize rooting depth was used as the soil depth to calculate the available water content $\left(A W C_{\text {maize }}\right)$, the range of $A W C_{\text {maize }}$ values and the mean and median $A W C_{\text {maize }}$ differed with the scenario (Table 3 ). The highest mean value of the $A W C_{\text {maize }}$ was recorded for scenario 2 and was equal to $124 \mathrm{~mm}$. The range of $A W C_{\text {maize }}$ values was larger for the scenario 2 than for the reference scenario.

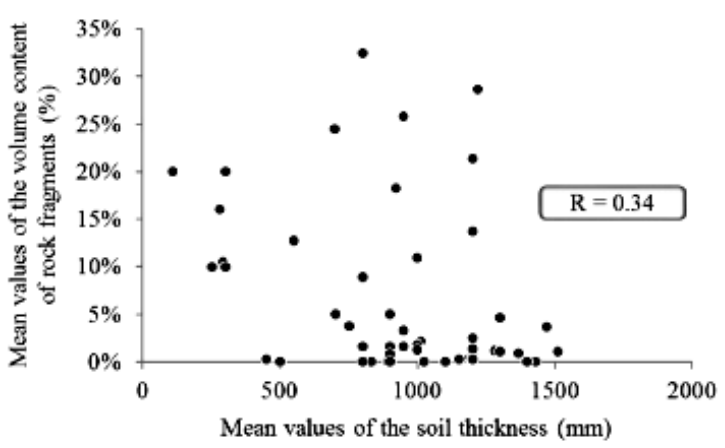

Fig. 3. Relationship between the mean values of rock fragment content and the mean soil thickness for each map unit. 
Version définitive du manuscrit publié dans / Final version of the manuscript published in :

Catena, 2015, 129, 95-102 http://dx.doi.org/10.1016/j.catena.2015.03.008

3.2.2. Spatial variability of the available water content calculated for the two depths and the 3 scenarios

The spatial variability of the available water content on the Patay map is presented in Figure 4. For the reference scenario (scenario 1), whatever the depth of calculation, the available water content ranged mainly from 50 to $150 \mathrm{~mm}$ for more than $70 \%$ of the map surface (Figs. 4a and 4a'). The main spatial feature of the $A W C_{\text {maize }}$ map was its relative homogeneity of the map, whereas the $A W C_{\text {soil }}$ map was more heterogeneous. For the $A W C_{\text {soil }}$ map, the minimum values - lower than $50 \mathrm{~mm}$ - were located in the south-central portion of the area, whereas the maximum values - larger than $150 \mathrm{~mm}$ - were rare (Fig. 4a). For scenarios 2 and 3, the minimum values of $A W C_{\text {soil }}$ and $A W C_{\text {maize }}$ - lower than $50 \mathrm{~mm}$ - were also in the south-central area. Regardless of the location, the available water content calculated when the rock fragments were considered to be inert (scenario 3) was systematically less than or equal to the available water content calculated when the soil was considered to contain fine earth only (scenario 2) (Figs. 4b, 4c, 4b'and 4c').

Table 3

Ranges of the soil available water content according to the different calculation scenarios. The scenario 1 is the reference scenario,

\begin{tabular}{|c|c|c|c|c|}
\hline & Minimum values (mm) & Mean values $(\mathrm{mm})$ & Median values (mm) & Maximum values ( $\mathrm{mm}$ ) \\
\hline & $A W C_{\text {soi }} A W C_{\text {maize }}$ & $A W C_{\text {soll }} A W C_{\text {malze }}$ & $A W C_{\text {soit }} A W C_{\text {maize }}$ & $A W C_{\text {soil }} A W C_{\text {malze }}$ \\
\hline Scenario 1 & 1356 & $104 \quad 124$ & $108 \quad 127$ & $190 \quad 170$ \\
\hline Scenario 2 & 1415 & $107 \quad 105$ & $109 \quad 153$ & 191182 \\
\hline Scenario 3 & $11 \quad 12$ & 10199 & $105 \quad 102$ & $189 \quad 169$ \\
\hline
\end{tabular}

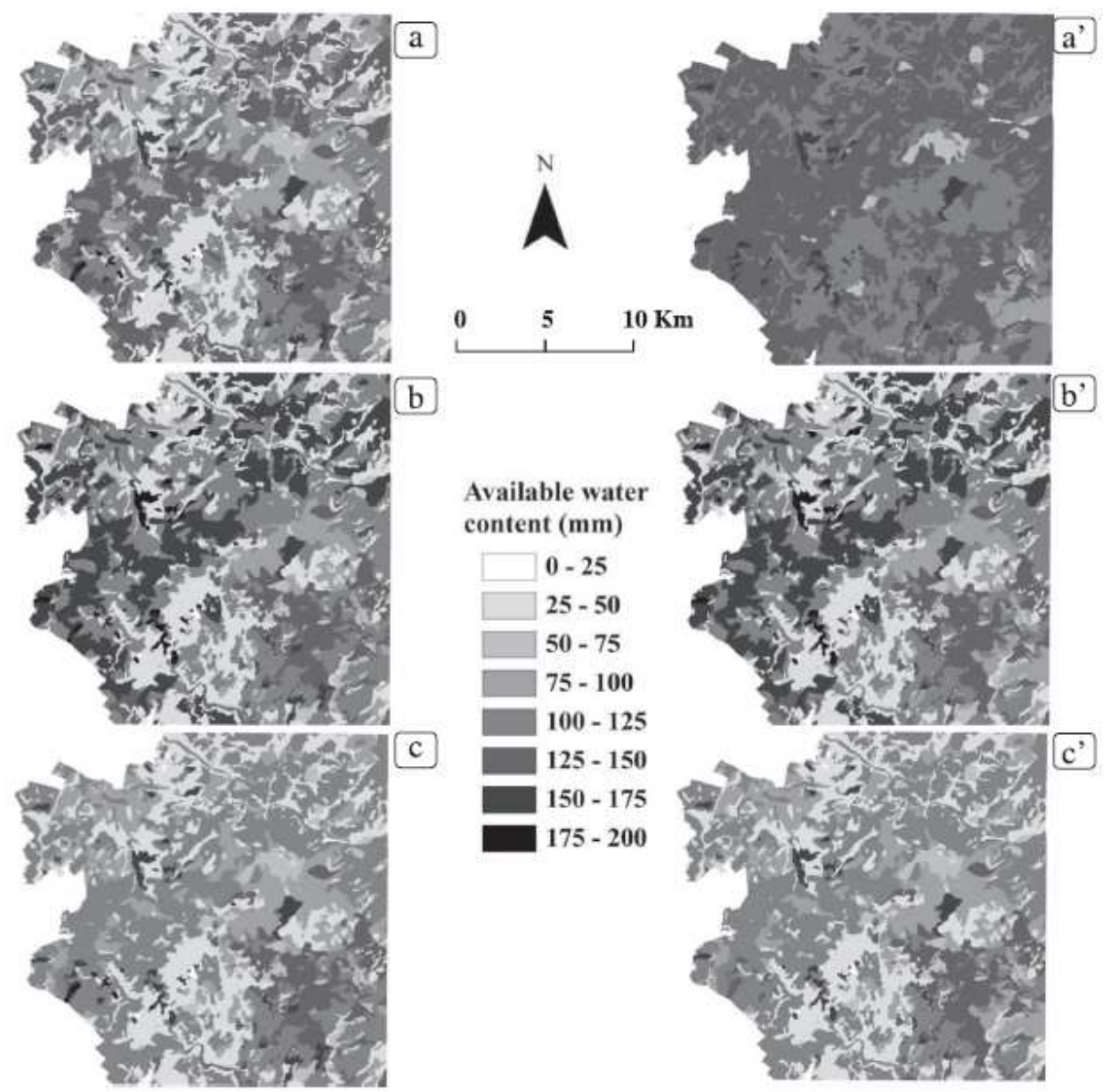

Fig. 4. Maps of the scil available water content (mm) calculated for the two soil depths and the three scenarios. a) $A W_{C_{\text {sai }}}$ Calculated for scenario 1 (reference scenario); b) $A W C_{\text {sail }}$ Calculated for scenario 2; c) $A W C_{\text {soil }}$ Calculated for scenario $3 . a^{\prime}$ ) $A W C_{\text {mpine }}$ calculated for scenario 1 (reference scenario); $b^{\prime}$ ) $A W C_{\text {mair }}$ calculated for scenario $2 ; c^{\prime}$ ) $A W C_{\text {maie }}$ Calculated for scenario 3. 


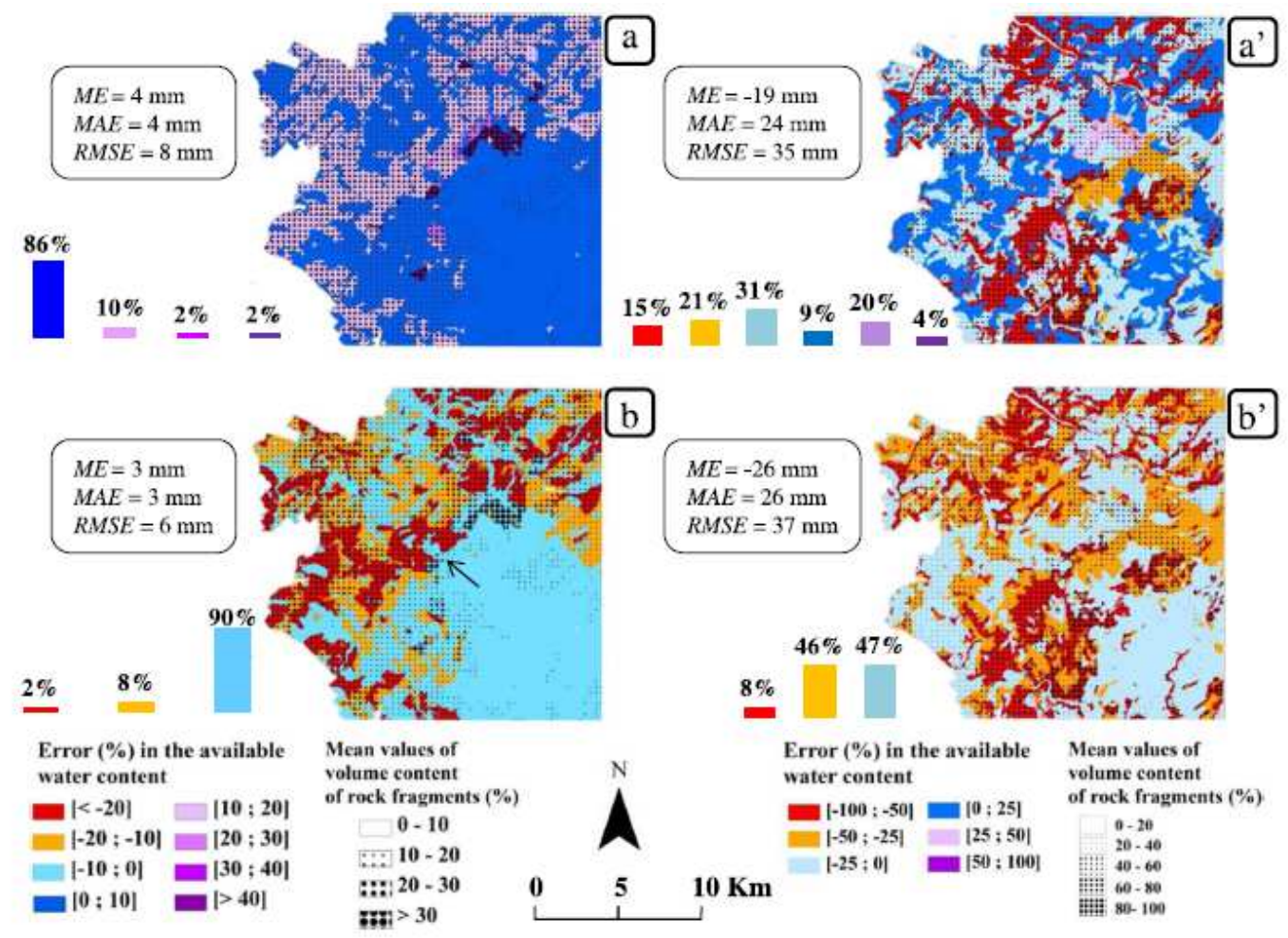

Fig. 5. Maps of the errors in the estimation of the soil available water content calculated for the two soil depths. a) Difference in $A W C_{\text {sou }}$ calculated for scenario 2 compared with scenario 1 : b) difference in $A W C_{\text {ouf }}$ calculated for scenario 3 compared with scenario $1 ; a^{\prime}$ ) difference in $A W C_{\text {maxix }}$ calculated for scenario 2 compared with scenario $1 ; b^{\prime}$ ) difference in $A W C_{\text {nuise }}$ calculated for scenario 3 compared with scenario 1.

\subsubsection{Mapping differences in available water content estimates}

The differences in available water content between scenarios 2 or 3 and the reference scenario are presented in figure 5. The $A W C_{\text {soil }}$ was systematically overestimated using scenario 2 compared with scenario 1 (Fig. 5a). By contrast, scenario 2 either underestimated or overestimated $A W C_{\text {maize }}$ compared with scenario 1 (Fig. 5a'). The overestimation, which covered $33 \%$ of the surface area, was usually located in areas with a low stoniness, for example in non-stony soils of the southeast part of the map or in deep soils with a low stoniness, as in the southwest-northeast band. Nevertheless, the $A W C_{\text {maize }}$ was overestimated in some highly stony areas, presumably when rock fragments could store only a small quantity of water, less than that stored in the fine earth (see in the central part of the map on figure 5a'). Figure 5a' also shows that the $A W C_{\text {maize }}$ was underestimated on $67 \%$ of the surface of the map. Depending on the texture of the fine earth and the lithological class of the rock fragments, the stony phase can store more water than the fine earth can. This situation occurred when the fine earth had a low available water content - sandy fine earth for example -, and when the rock fragments had a high available water content - porous limestone for example. In some stony areas, the $A W C_{\text {maize }}$ was underestimated by more than $50 \%$ (Fig. 5a'). These areas had thin soils, and the $A W C_{\text {maize }}$ was calculated by assuming that much of the subsoil explored by the maize roots consisted of parent material. As explained in the materials and method sections, we have hypothesized that the available water content of the subsoil was the same as that of the rock fragments in the soil.

For the scenario 3 , in which the stony phase was considered to be inert, the available water content (both $A W C_{\text {soil }}$ and $A W C_{\text {maize }}$ ) was systematically underestimated. In areas with low rock fragments content (the southeast part of the soil map on Figs. $5 b$ and 5b', for example), the differences between scenario 1 and scenario 3 were minor (less than $10 \%$ ), as expected. In some very stony areas (see the black arrow in Fig. 5b), the difference between scenarios 3 
Version définitive du manuscrit publié dans / Final version of the manuscript published in : Catena, 2015, 129, 95-102 http://dx.doi.org/10.1016/j.catena.2015.03.008

and 1 for $A W C_{\text {soil }}$ was minor as well (less than $10 \%$ ): in these areas, the rock fragments were quartz or flint, which are rock fragments with a quasi-null water retention capacity. By contrast, large surface areas characterized by highly rocky soils exhibited $A W C_{\text {soil }}$ and $A W C_{\text {maize }}$ values that were lower in scenario 3 than in 1: in these cases, rock fragments can retain significant quantities of water and must not be neglected when evaluating the available water content of soil.

3.2.4. Effect of soil thickness and soil stoniness on the estimation of the available water content

The relationships between the thickness and soil stoniness of soils and the errors in the $A W C_{\text {soil }}$ values estimated using scenarios 2 and 3 compared with 1 are presented in Figures $6 \mathrm{a}$ and $6 \mathrm{~b}$. As might be expected, the errors were the lowest not only for soils with a low stoniness, but also for the shallowest soils. No obvious relationship between the errors on the $A W C_{\text {soil }}$ estimation and the thickness or stoniness was observed.

\section{scale \\ 3.3. Assumptions used to estimate the available water content at a regional}

We have defined the available water content as the quantity of water that can be used by plant for their growth. It is typically defined as the difference between the water content at field capacity, and the water content at permanent wilting point. In our calculations, we have determined that the water content at field capacity could be considered equal to the water content at $-100 \mathrm{hPa}$, as demonstrated by Bruand et al. (2004) for fine earth, and by Tetegan et al. (2011) for rock fragments. Nevertheless, this value of water potential at field capacity, that has been shown to be true in our study could be changed and should be adapted in other contexts: for example, it could be adjusted to $-330 \mathrm{hPa}$ (Bruand et al., 2004) for more clayey soils, or, even $-500 \mathrm{hPa}$, as suggested by Whalley et al. (2005) for some crops, when available water contents are used in crop models.
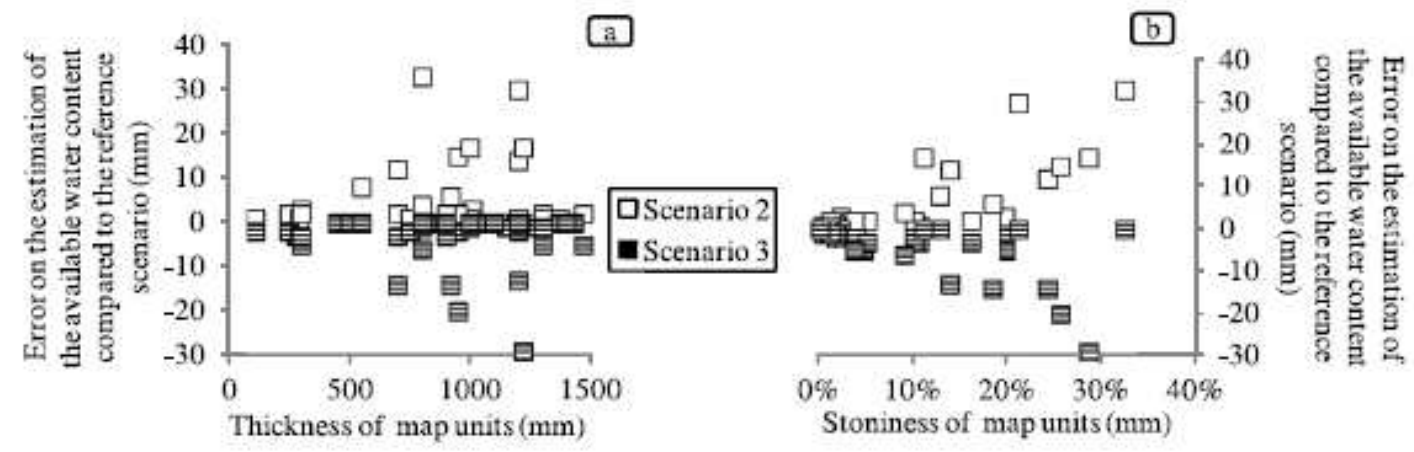

Fig. 6. Relationship between the errors in estimation of the available water content ( $A W C_{\text {soii }}$ ) and a) the soil thickness and $b$ ) the soil stoniness.

For the permanent wilting point, we have used the classic value of water potential equal to $15850 \mathrm{hPa}$ that can be calculated by pedotransfer functions and is commonly used by soil scientists. This value can be used with mature plants; however, it is known that the real value of permanent the wilting point depends on both the soil (especially the soil texture) and the physiological characteristics of the plant, as demonstrated by Czyz and Dexter (2012). Plants from humid zones would not survive such low $\mathrm{pF}$ values and their permanent wilting point 
Version définitive du manuscrit publié dans / Final version of the manuscript published in :

Catena, 2015, 129, 95-102 http://dx.doi.org/10.1016/j.catena.2015.03.008

would be lower. In contrast, desert plants, if we choose an extreme, will survive extremely low $\mathrm{pF}$ values (about - 163,000 hPa for Artemisia Herba Alba (Gobat et al., 2003) The results obtained here at a regional scale, where all the crops are considered to be maize, could then be different for other crops where the water potential at field capacity may be different for physical reasons, and both the water potential at the permanent wilting point and the soil depth could be different for agronomic and/or ecophysiological reasons.

\section{Conclusions}

The available water content of the stony soils of Patay was calculated using pedotransfer classes proposed by Bruand et al. (2004) for the fine earth and Tetegan et al. (2011) for the rock fragments. We demonstrated that the $A W C$ calculated by assuming that the stony soil was completely composed of fine earth led either to overestimations or underestimations of the real $A W C$ calculated when both the proportion and the water -holding capacities of the stony phase are taken into account. We also demonstrated that the $A W C$ calculated by assuming that the stony soils considered to consist of fine earth and non porous rock fragments led to systematic underestimation (up to 20\%) of the real $A W C$. Estimation of the available water content, and thus of the soil water deficit, was strongly dependent on value of the soil thickness which was considered in the calculations.

From these maps and the associated databases, the water demand of crops in the study area can be calculated. In the context of climate change, which is expected to intensify droughts and increase the need for irrigation, this will enable a more accurate calculation of the water deficit and will be beneficial for farmers and regional planning of irrigation needs. If these maps are to be used as spatial data input for regional water balance modelling, our results demonstrate that failing to account for the rock fragments may lead to erroneous conclusions and unappropriated recommendations.

\section{References}

Abou-el-Seoud, I.I., and Abdel-Megeed, A., 2012. Impact of rock materials and biofertilizations on $\mathrm{P}$ and $\mathrm{K}$ availability for maize (Zea Maize) under calcareous soil conditions. Saudi Journal of Biological Sciences 19 (1), 55-63.

Al Majou, H., Bruand, A., Nicoullaud, B., Duval, O., Dupont, J., 2005. Premiers résultats de validation des classes de pédotransfert établies à partir de la base de données SOLHYDRO 1.0: application à des sols de la région centre. Etud. Gest. Sols 12 (3), 221-228.

Al Majou, H., Bruand, A., Duval, O., Cousin, I., 2007. Variation of the water retention properties of soils: validity of class-pedotransfer functions. Comptes Rendus Geoscience 339 (9), 632-639.

Al Majou, H., Bruand, A., Duval, O., Le Bas, C., Vautier, A., 2008a. Prediction of soil water retention properties after stratification by combining texture, bulk density and the type of horizon. Soil Use Manage. 24, 383-391.

Al Majou, H., Bruand, A., Duval, O., 2008b. Use of in situ volumetric water content to improve prediction of soil water retention properties. Can. J. Soil Sci. 88, 522-541.

Baize, D., Girard, M.C., Jabiol, B., Rossignol, J.P., Eimberck, M., Beaudou, A., 2009. Référentiel pédologique 2008. Association Française pour l'Etude des sols. Coll. Savoir Faire. Quae Editions. France, p. 435.

Bastet, G., Bruand, A., Voltz, M., Bornand, M., Quétin, P., 1999. Performance of available pedotransfer functions for predicting the water retention properties of French soils, in: 
Version définitive du manuscrit publié dans / Final version of the manuscript published in :

Catena, 2015, 129, 95-102 http://dx.doi.org/10.1016/j.catena.2015.03.008

Van Genuchten, M.Th., Leij, F.J., Wu, L. (Eds.), Proceedings of the International Workshop on Characterization and Measurement of the Hydraulic Properties of Unsaturated Porous Media, Parts 1 and 2. University of California, Riverside, CA, pp. 981-992.

Bourennane, H., King, D., Chéry, P. \& Bruand, A. 1996. Improving the kriging of a soil variable using slope gradient as external drift. Eur. J. Soil Sci. 47, 473-483.

Bourennane, H., King, D., Parco, R.L., Isambert, M., Tabbagh, A., 1998. Three dimensional analysis of soils and surface materials by electrical resistivity survey. Eur. J. Environ. Eng. Geophys. 3, 5-23.

Bruand, A., Fernandez, P. P., Duval, O., Quétin, P., Nicoullaud, B., Gaillard, H., Raison, L., Pessaud, J.-F., Prud'Homme, L., 2002. Estimation des propriétés de rétention en eau des sols: utilisation de classes de pédotransfert après stratifications texturale et texturostructurale. Etud. Gest. Sols 9 (2), 105-126.

Bruand, A., Duval, O., Cousin, I., 2004. Estimation des propriétés de rétention en eau des sols à partir de la base de données SOLHYDRO: Une première proposition combinant le type d'horizon, sa texture et sa densité apparente. Etud. Gest. Sols 11 (3), 323-334.

B.S.I. Standards, 1988. Draft code of practice for the planning design and installation of irrigation schemes in the UK. Part 2. Irrigation water requirements. B.S.I. Standards, Technical Commitee AGE/30, Irrigation and drainage equipment, $n^{\circ}$ 88/73803 DC.

Corti, G., Ugolini, F.C., Agnelli, A., 1998. Classing the soil skeleton (greater than two millimeters): Proposed approach and procedure. Soil Sci. Soc. Am. J. 62 (6), 16201629.

Cousin, I., Nicoullaud, B., Coutadeur, C., 2003. Influence of rock fragments on the water retention and water percolation in a calcareous soil. Catena 53 (2), 97-114. Doorenbos, J., Kassam, A.H., Bentvelder, C., Uittenboogaard, G., 1978. Yield response to water. In: FAO irrigation and drainage paper 33, FAO, Rome, Italy, p.144.

Czyz, E.A., Dexter, A.R., 2012. Plant wilting can be caused either by the plant or by the soil. Soil Research 50 (8), 708-713.

Frison, A., Cousin, I., Montagne, D., Cornu, S., 2009. Soil hydraulic properties in relation to local rapid soil changes induced by field drainage: a case study. Eur. J. Soil Sci. 60, 662-670.

Gaultier J.P., Legros J.P., Bornand M., King D., Favrot J.C. Hardy R., 1993. L'organisation et la gestion des données pédologiques spatialisées : le projet DONESOL. Revue de Géomatique 3, 235-253.

Garcia-Ruiz, J.M., Lopez-Moreno, J.I., Vicente-Serrano, S.M., Lasanta-Martinez, T., Begueria, S., 2011. Mediterranean water resources in a global change scenario. EarthSci. Rev. 105 (3-4), 121-139.

Gobat, J.M., Aragno, M., Matthey, W., 2003. Le sol vivant: Bases de pédologie, biologie des sols. Presses Polytechniques et Universitaires Romandes (PPUR), 568 p.

Gras, R. and Monnier, G., 1963. Contribution de certains éléments grossiers à l'alimentation en eau des végétaux. Sci. Sol. 1, 13-20.

Grolleau, E., Bargeot, L., Chafchafi, A., Hardy, R., Doux, J., Beaudou, A., Le Martret, H., Lacassin, J.C., Fort, J.L., Falipou, P., Arrouays, D., 2004. Le système d'information national sur les sols : DONESOL et les outils associés. Etud. Gest. Sols 11 (3), 255270.

IUSS Working Group WRB, 2006. World reference base for soil resources 2006. 2nd Edition. World Soil Resources Reports No. 103. FAO, Rome.

Jamagne, M., 1967. Bases et techniques d'une cartographie des sols. Annales Agronomiques 18. France. p. 142. 
Version définitive du manuscrit publié dans / Final version of the manuscript published in :

Catena, 2015, 129, 95-102 http://dx.doi.org/10.1016/j.catena.2015.03.008

Jamagne, M., Bétrémieux, R., Bégon, J.C., Mori, A., 1977. Quelques données sur la variabilité dans le milieu naturel de la réserve en eau des sols. Bulletin Technique d'Information 324, 627-641.

Jensen, C.R., Battilani, A., Plauborg, F., Psarras, G., Chartzoulakis, K., Janowiak, F., Stikic, R., Jovanovic, Z., Li, GT., Qi, XB., Liu, FL., Jacobsen, S-E., Andersen, M.N., 2010. Deficit irrigation based on drought tolerance and root signalling in potatoes and tomatoes. Agric. Water Manage. 98 (3), 403-413.

King, D., Bourennane, H., Isambert, M., Macaire, J.J., 1999. Relationship of the presence of a non-calcareous clay-loam horizon to DEM attributes in a gently sloping area. Geoderma 89, 95-111.

Korboulewsky, N., Besnault, A., Tétégan, M., Cousin, I., 2010b, May. Contribution of rock fragments to soil fertility. In EGU General Assembly Conference Abstracts, 12, p. 6558 .

Korboulewsky, N., Tétégan, M., Besnault, A., Cousin, I., 2010b, May. Do rock fragments participate to plant water and mineral nutrition? In EGU General Assembly Conference Abstracts, 12, p. 6537.

Legros, J-P., 2006. Mapping of the soil. Translated from the French by V.A.K. Sarma. Science Publishers, Enfield NH, Jersey, Plymouth. USA.

Li, H.B., Zhang, F.S., Shen, J.B., 2012. Contribution of root proliferation in nutrient-rich soil patches to nutrient uptake and growth of maize. Pedosphere 22 (6), 776-784.

Lorain, J-M., 1973. La géologie du calcaire de Beauce. In : Le calcaire de Beauce - géologie, hydrogéologie, applications en construction routière et génie civil. Paris - Ministère de l'Aménagement du territoire Editions. Bulletin de liaison des laboratoires des Ponts et Chaussées, pp. 14-53.

Macaire, J.M. 1971. Etude sédimentologique des formations superficielles sur le tracé de l'autoroute A10 entre Artenay et Meung sur Loire. PhD thesis, Univ. Orleans, France.

Nicoullaud, B., Couturier, A., Beaudoin, N., Mary, B., Coutadeur, C., King, D., 2004. Modélisation spatiale à l'échelle parcellaire des effets de la variabilité des sols et des pratiques culturales sur la pollution nitrique agricole, in: Monestiez, P., Lardon, S., Seguin, B. (Eds.), Organisation spatiale des activités agricoles et processus environnementaux. Coll. Science Update, INRA Editions, pp. 143-161.

Paydar, Z., Gaydon, D., Chen, Y., 2009. A methodology for up-scaling irrigation losses. Irrigation Sci. 27, 347-356.

Poesen, J., Lavee, H., 1994. Rock fragments in top soils: significance and processes. Catena 23, 1-28.

Richer de Forges, A., Verbèque, B., 2003. Carte des sols de Patay (Loiret) au 1/50 000 et notice explicative. Chambre d'Agriculture du Loiret, INRA publications, France.

Tetegan, M., Nicoullaud, B., Baize, D., Bouthier, A., Cousin, I., 2011. The contribution of rock fragments to the available water content of stony soils: proposition of new pedotransfer functions. Geoderma 165 (1), 40-49.

Wang, H., Xiao, B., Wang, M., Shao, M., 2013. Modeling the Soil Water Retention Curves of Soil-Gravel Mixtures with Regression Method on the Loess Plateau of China. PLoS ONE 8 (3), e59475.

Whalley W.R., Riseley B., Leeds-Harrison P.B., Bird N.R.A., Leech P.K., Adderley W.P., 2005. Structural differences between bulk and rhizosphere soil. Eur. J. Soil Sci. 56, 353-360.

Wösten, J.H.M., Pachepsky, Y.A., Rawls, W.J., 2001. Pedotransfer functions: bridging the gap between available basic soil data and missing soil hydraulic characteristics. J. Hydrol. 251, 123-150. 
Version définitive du manuscrit publié dans / Final version of the manuscript published in :

Catena, 2015, 129, 95-102 http://dx.doi.org/10.1016/j.catena.2015.03.008

\section{Figure captions:}

Figure 1: Map of the soil thickness in the area of Patay. Four synthetic characteristic soil profiles are represented (from Richer de Forges and Verbèque, 2003).

Figure 2: Rock fragments content and types, in the area of Patay. a) Primary of rock fragments type; b) Rock fragments content observed in the field (information stored in the soil database ; c) Rock fragments content recalculated for a soil thickness of 120 $\mathrm{cm}$.

Figure 3: Relationship between the mean values of rock fragment content and the mean soil thickness for each map unit.

Figure 4: Maps of the soil available water content $(\mathrm{mm})$ calculated for the two soil depths and the three scenarios. a) $A W C_{\text {soil }}$ calculated for the scenario 1 (reference scenario); b) $A W C_{\text {soil }}$ calculated for the scenario 2 ; c) $A W C_{\text {soil }}$ calculated for the scenario 3. a') $A W C_{\text {maize }}$ calculated for the scenario 1 (reference scenario); b') $A W C_{\text {maize }}$ calculated for the scenario 2 ; c') $A W C_{\text {maize }}$ calculated for the scenario 3.

Figure 5: Maps of the errors in the estimation of the soil available water content calculated for the two soil depths. a) Difference in $A W C_{\text {soil }}$ calculated for scenario 2 compared with scenario 1 ; b) Difference in $A W C_{\text {soil }}$ calculated for scenario 3 compared with scenario 1 ; a') Difference in $A W C_{\text {maize }}$ calculated for scenario 2 compared with scenario 1 ; b') Difference in $A W C_{\text {maize }}$ calculated for scenario 3 compared with scenario 1.

Figure 6: Relationship between the errors in estimation of the available water content $\left(A W C_{\text {soil }}\right)$ and a) the soil thickness and b) the soil stoniness.

\section{List of tables:}

Table 1: The pedotransfer classes used in the equation Eq. (1) for the calculation of the available water content $\left(A W C_{i}\right)$ of the fine phase as a function of both the position of the horizon in the soil profile and the texture of the fine earth texture (From Bruand et al., 2004).

Table 2: Available water content $\left(A W C_{i}\right)$ of the stony phase calculated from the pedotransfer classes of Tetegan et al. (2011).

Table 3: Ranges of the soil available water content according to the different calculation scenarios. The scenario 1 is the reference scenario. 